\title{
Infective endocarditis by Proteus species: a systematic review
}

\author{
Petros Ioannou ${ }^{1, *}$, Georgios Vougiouklakis ${ }^{2}$
}

\section{Abstract}

Proteus spp. are members of the Enterobacteriaceae family and are Gram-negative, rod-shaped bacteria known to mainly cause urinary tract infections (UTIs) in humans. However, even though scarce evidence exists suggesting their potential to cause infective endocarditis (IE), a study summarizing the existing evidence is lacking. The purpose of this study was to systemically review all published cases of IE by Proteus species in the literature. A systematic review of PubMed, Scopus and Cochrane Library (through $5^{\text {th }}$ May 2020) for studies providing epidemiological, clinical and microbiological data as well as data on treatment and outcomes of IE by Proteus species was performed. A total of 16 studies, containing data of 16 patients, were included. A prosthetic valve was present in $25 \%$, while the most common causative pathogen was $P$. mirabilis. Aortic valve was the most common infected site in $33.3 \%$, followed by mitral valve in $26.7 \%$. Diagnosis was set with transesophageal echocardiography in $37.5 \%$, and transthoracic echocardiography in $25 \%$, while the diagnosis was set at autopsy in $25 \%$. Fever and sepsis were present in $100 \%$ and $84.6 \%$, respectively. Aminoglycosides and cephalosporins were the most common antimicrobials used for treatment. Clinical cure was noted in $62.5 \%$, while overall mortality was $43.8 \%$. This systematic review describes IE by Proteus species in detail and provides information on epidemiology, clinical presentation, treatment and outcomes.

Keywords Endocarditis, systematic review, Proteus, P. mirabilis.

\section{Introduction}

Proteus spp. are members of the Enterobacteriaceae family and are motile, lactosenegative, urease-producing, Gram-negative, rodshaped bacteria that are able to differentiate from typical enterobacterial bacilli into highly elongated rods covered with thousands of flagella, thus producing swarming colonies. ${ }^{1-3}$ Even though there are several species of the Proteus genus, the vast majority of the isolated clinical

Received: 21 May 2020; revised: 29 July 2020; accepted: 29 July 2020.

${ }^{1} \mathrm{MD}, \mathrm{MSc}, \mathrm{PhD}$, Department of Internal Medicine \& Infectious Diseases, University Hospital of Heraklion, Stavrakia and Voutes crossroad, Heraklion, PC 71110, Crete, Greece; ${ }^{2}$ Department of Internal Medicine \& Infectious Diseases, University Hospital of Heraklion, Stavrakia and Voutes crossroad, Heraklion, PC 71110, Crete, Greece.

${ }^{*}$ Corresponding author: Petros Ioannou; p.ioannou@med.uoc.gr

Article downloaded from www.germs.ro

Published September 2020

(c) GERMS 2020

ISSN $2248-2997$

ISSN - L = 2248 - 2997 isolates are P. mirabilis and P. vulgaris. ${ }^{1}$ Proteus spp. are most commonly associated with urinary tract infections (UTIs), both in regular hosts, as well as in patients with indwelling catheters and anatomic or functional abnormalities of the urinary tract. ${ }^{1,3}$

P. mirabilis, due to its flagella and the production of adhesins, can form biofilms quite quickly and easily, leading to fouling of foreign materials, such as urinary tract catheters. ${ }^{4}$ This ability to form biofilms is associated with its ability to cause UTIs. ${ }^{3}$ Furthermore, Proteus spp. are commonly isolated from the blood of patients, more commonly in the context of a UTI. ${ }^{5}$ Importantly, Proteus spp. have been associated with several other infections beyond UTIs, such as primary bacteremias and more rarely with other types of infections, such as respiratory tract, or wound infections. ${ }^{5}$

The ability of Proteus to form biofilms, in combination with its ability to cause bacteremia, could denote the potential to cause complicated bloodstream infections, such as infective endocarditis (IE), which is of particular importance, due to the notable morbidity and mortality that IE carries. ${ }^{6,7}$ Due to its rarity, IE by 
Gram-negative bacteria poses therapeutic dilemmas due to the lack of adequate experience and clear guidelines on how to treat these infections. ${ }^{7}$ Interestingly, even though there are some case reports with short literature reviews summarizing the characteristics of IE by Proteus species, a review adequately summarizing all available evidence in the literature is lacking. ${ }^{8}$

The aim of this paper was to systemically review all published cases of IE by Proteus species in the literature and describe the epidemiology, microbiology, clinical characteristics, treatment and outcomes of these infections.

\section{Methods}

\section{Data search}

For this study, we adopted the Meta-analysis of observational studies in epidemiology (MOOSE) guidelines. ${ }^{9}$ Eligible studies were identified through search of PubMed, Scopus and Cochrane Library with the following terms: Proteus AND endocarditis. Day of last search was $5^{\text {th }}$ May 2020.

\section{Study selection}

Studies meeting the following criteria were included in analysis: 1) published in English; 2) reporting data on patients' clinical characteristics, microbiology, treatment and outcomes. Studies with the following criteria were excluded from the analysis: 1) secondary research papers (e.g., reviews), editorials and papers not reporting results on primary research; 2) studies not in humans; 3) studies not in English. Two investigators (PI, GV) using Abstrackr ${ }^{10}$ independently reviewed the titles and abstracts of the resulting references and then they retrieved and rescreened the full text publications of potentially relevant articles. Study selection was based on consensus. Reference lists of included studies were searched for relevant articles.

\section{Outcomes of interest}

The primary outcomes of the study were to record data on: a) epidemiology of patients with IE by Proteus species and b) patients' outcomes. Secondary outcomes were to record data on: a) the exact site of infection, b) the clinical characteristics of the patients, c) antimicrobial susceptibility and d) their treatment. Finally, another endpoint was the identification of independent risk factors for mortality by these infections.

\section{Data extraction and definitions}

Data from each eligible study were extracted by two investigators (PI, GV). The extracted data included study type, year of publication and country; patient demographic data (age and gender); patient's relevant medical history (previous cardiac surgery or cardiac valve replacement, time after cardiac valve replacement); infection data and microbiology (infection site, isolated strains, presence of complications, presence of embolic phenomena); treatment administered for IE; and outcomes (i.e., cure or death). Data on microbiology and relation of death to the index infection was reported according to the study authors. Diagnosis of IE was confirmed by the investigators based on the information provided by the authors and the modified Dukes' criteria if the diagnosis was at least possible (at least 1 major and 1 minor criterion or at least 3 minor criteria) or if pathological data established a diagnosis of IE. ${ }^{11}$ The complications recorded included any organ dysfunction or clinical deterioration that was considered by the authors to be related to the IE. The quality of evidence of the outcomes of included studies was assessed using the Grading of recommendations assessment, development and evaluation (GRADE). ${ }^{12}$

\section{Statistical analysis}

Data are presented as number (\%) for categorical variables and median (interquartile range, IQR) or mean ( \pm standard deviation, SD) for continuous variables. A univariate linear regression analysis was conducted to identify factors associated with all-cause mortality and IEspecific mortality of patients with IE by Proteus species. The above-mentioned statistics were calculated with GraphPad Prism 6.0 (GraphPad Software, Inc., San Diego, CA). 
Results

Literature search

A total of 294 articles from PubMed, Scopus and Cochrane Library were screened. After reviewing the titles and abstracts, 23 articles were selected for full-text review. ${ }^{13-35}$ From these studies, 8 were excluded from the review: 3 had non-extractable data, ${ }^{28-30} 2$ did not describe IE by Proteus, ${ }^{31,32} 1$ full text could not be found, ${ }^{33} 1$ did not include any outcomes of interest ${ }^{34}$ and 1 study was a secondary research article (review). ${ }^{35}$ One additional study was found during the handscreening of the included articles' references. Finally, 16 met the present study's inclusion criteria., ${ }^{8,13-27}$ The review process is graphically presented in Figure 1.

\section{Included studies' characteristics}

The 16 studies that were finally included in the present analysis involved 16 patients in total. Table 1 (appendix) summarizes the characteristics of included studies. Among those studies, 10 were conducted in North and South America, 5 in Europe and 1 in Asia. There were 13 case reports and 3 case series, thus, the overall quality of the evidence that contributed to this systematic review was rated as low to very low, implying that further research is very likely to have an important impact on our confidence in the data presented in this systematic review. ${ }^{12}$

\section{Epidemiology of IE by Proteus species}

Age of patients ranged from 1 to 71 years, mean age was 52.4 years, and $56.3 \%$ (9 out of 16 patients) were male. A prosthetic cardiac valve was present in $25 \%$ (4 out of 16 patients) and was metallic in 1 patient and bioprosthetic in 3 patients. Furthermore, $18.8 \%$ (3 patients) had a history of intravenous drug use (IVDU), $12.5 \%$ (2 patients) had a history of a previous IE, 6.3\% (1 patient) had a central venous catheter and $6.3 \%$ (1 patient) had a foreign material in the heart (bristle) due to unintended ingestion. The characteristics of patients with IE by Proteus species can be seen in Table 2 (Apendix).
Microbiology of IE and antimicrobial resistance of Proteus species

The most commonly identified species was $P$. mirabilis in $87.5 \%$ (14 out of 16 patients), $P$. vulgaris in 6.3 ( 1 patient), while in $6.3 \%$ (1 patient), the species were not specified. $S$. aureus and E. coli were isolated in $6.3 \%$ (1 patient) of IE each. Resistance to trimethoprimsulfamethoxazole was noted in $33.3 \%$ ( 1 out of 3 patients), to quinolones in 25\% (1 out of 4 patients), to aminopenicillins in $16.7 \%$ ( 1 out of 6 patients), while no resistance was noted to cephalosporins, piperacillin/tazobactam, carbapenems, and aminoglycosides.

\section{Diagnosis of IE by Proteus species}

The most common site of infection was the aortic valve in $33.3 \%$ ( 5 out of 15 patients with available data), the mitral valve in $26.7 \%$ (4 patients), the tricuspid valve in $20 \%$ (3 patients), the mural endocardium in $12.5 \%$ ( 2 patients) and the eustachian valve in $6.3 \%$ (1 patient). Diagnosis was set with transesophageal echocardiography in $37.5 \%$ (6 out of 16 patients), with transthoracic echocardiography in $25 \%$ (4 patients), at autopsy in 25\% (4 patients), through valve culture in $6.3 \%$ (1 patient) while diagnosis was set empirically due to nondiagnostic echocardiography in $6.3 \%$ (1 patient). In the last case, the patient presented with signs and symptoms of IE and was treated as such, while according to the Duke criteria, diagnosis of IE was possible (one major and one minor criterion), thus, this study was included in this analysis.

\section{Clinical characteristics of IE by Proteus species}

Fever was present in $100 \%$ (15 out of 15 patients with available data); sepsis in 84.6\% (11 out of 13 patients with available data), a concurrent UTI in $43.8 \%$ (7 out of 16 patients), while embolic phenomena occurred in $42.9 \%$ (6 out of 14 patients with available data) and immunologic phenomena and heart failure in $14.3 \%$ ( 2 out of 14 patients) each. Furthermore, $13.3 \%$ ( 2 out of 15 patients with available data) developed a paravalvular abscess, and a skin and 


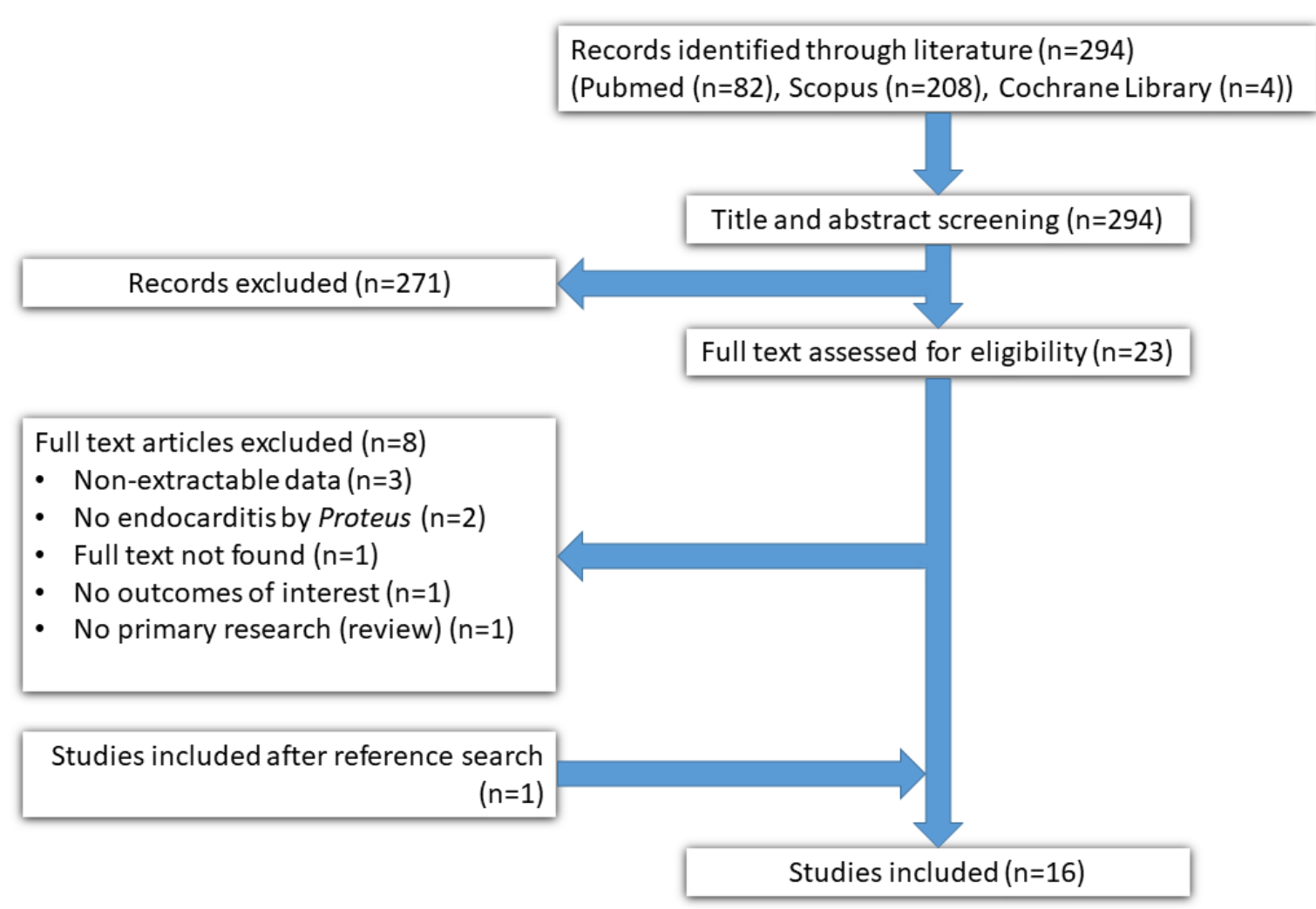

Figure 1. Flow diagram of study inclusion

soft tissue infection (SSTI) was present in $6.3 \%$ (1 out of 16 patients).

Treatment and outcomes of IE by Proteus species

Treatment administered for IE by Proteus species can be seen in detail in Table 1 and in summary in Table 2. Duration of treatment among survivors ranged from 4 to 6 weeks, with a median duration of 6 weeks. Surgical intervention was performed in $31.3 \%$ (5 out of 16 patients). Clinical cure was achieved in $62.3 \%$ (10 out of 16 patients), overall mortality was $43.8 \%$ ( 7 patients) and the mortality attributed directly to IE was $31.3 \%$ (5 patients).

\section{Statistical analysis of IE by Proteus species}

We performed a univariate linear regression analysis in order to identify any association between gender, age, being an IVDU, having a prosthetic cardiac valve, concurrent UTI, having IE at the aortic, the mitral or the tricuspid valve, presenting with sepsis or embolic phenomena, treatment with aminoglycosides or cephalosporins, and having a surgery, with overall mortality and IE-specific mortality. The analysis did not identify any statistically significant association with mortality.

\section{Discussion}

IE is an uncommon disease that carries a significant mortality and is mostly caused by Gram-positive microorganisms. However, Gramnegative microorganisms may be involved in some cases of IE. ${ }^{28,36}$ More specifically, IE by Proteus species is a very rare disease. Thus, even though there are some case reports in the literature, there is no study summarizing its characteristics. To our knowledge, this is the first study that systematically reviews IE by Proteus species, and provides thorough information on its clinical and microbiological characteristics, as well as data on treatment and outcomes.

Mean age at diagnosis of patients with Proteus IE herein was 52.4 years, while a slight male predominance was noted; findings that share similarity with IE caused by non-HACEK Gram- 
negative bacteria (NHGNB) according to literature. ${ }^{28,29,37}$ Among all patients with IE by Proteus species, $25 \%$ had a prosthetic cardiac valve, which is similar to the rate in other studies that ranged from $19 \%$ to $67 \% .^{28,37-39}$ Furthermore, $12.5 \%$ of patients with IE by Proteus species had a previous episode of IE, while, in other studies, that rate ranged from $3.8 \%$ to $67 \% .^{28,37-39}$ Finally, $18.8 \%$ of patients with IE by Proteus species were IVDU, while the rate of IVDU patients with IE by NHGNB in the literature varied widely from $0 \%$ to $93 \%{ }^{28,37-39}$

The most commonly infected intracardiac sites were the aortic valve in $33.3 \%$ and the mitral valve in $26.7 \%$. In other studies, with IE by NHGNB, the infected sites differed, with the aortic valve being most commonly infected in $42 \%$, followed by the tricuspid valve in $33 \%$ in one study ${ }^{37}$ and the mitral valve being the commonest infected valve in $31 \%$, followed by the aortic valve in $24 \%$ in another study. ${ }^{28}$

Regarding clinical presentation, fever was the most common symptom, and it occurred in all patients with available data, while $84.6 \%$ of patients were septic. In studies with IE caused by NHGNB, presence of fever ranged from $77 \%$ to 92\%. ${ }^{37,38}$ Among patients with Proteus IE, 14.3\% developed heart failure, which is similar to the rate in other studies that ranged from $8 \%$ to $38 \% .^{28,29,37,38}$ Embolic and immunologic phenomena in Proteus IE were present in $42.9 \%$ and $14.3 \%$ respectively, which are similar to the rates in IE caused by NHGNB that ranged from $14 \%$ to $65 \%$ and from $8 \%$ to $40 \%$ respectively. ${ }^{28,37-39}$ A paravalvular abscess occurred in $13.3 \%$ of patients with IE by Proteus species, which approximates the rate of abscess development in IE by NHGNB, that ranged from $5.2 \%$ to $42 \%$. $^{28,37,39}$

Among the studies included in this systematic review, the most common species causing IE was $P$. mirabilis, while in one case $P$. vulgaris was identified and in one remaining case the species was not noted. This is, however, in line with the literature that shows that, in general, $P$. mirabilis is the most clinically relevant species causing human infection. ${ }^{1}$ Interestingly, a close association of IE with concomitant UTI was noted, since $43.8 \%$ of patients with IE had a diagnosis of UTI at the same time, which confirms the predilection of this pathogen to causing UTIs. ${ }^{1,3}$ In terms of pathophysiology, the most reasonable scenario would be that a UTI led to bacteremia and that led to IE. However, based on the data provided from the included studies, one cannot exclude the possibility of a bacteremia due to IE leading to bacterial seeding of the kidneys and secondary UTI.

Proteus spp. are not globally considered to pose a significant problem in terms of antimicrobial resistance until now. This systematic review identified resistance of Proteus strains to co-trimoxazole and quinolones in up to $33 \%$, while the resistance to other antimicrobials was minimal. However, many of the studies were old, and may not represent the current trends of antimicrobial resistance. Additionally, few studies provided data on antimicrobial resistance and thus, this information should be read with caution. These data come to confirm the literature, where increased resistance of Proteus strains to co-trimoxazole and quinolones has been noted, even though those resistance rates were higher than in this systematic review. ${ }^{40}$

Given the above, it is no surprise that for the treatment of IE by Proteus species, aminoglycosides, cephalosporins and aminopenicillins were the most common antimicrobials used, while quinolones and carbapenems were used in fewer cases. Mortality was, however, high, with two out of five patients dying and the vast majority of them dying specifically due to the IE by Proteus which was higher than the rate in studies of IE by NHGNB, where mortality ranged from $5 \%$ to $24 \%$. $^{28,29,38,39}$ However, it should be noted that even though the in-hospital mortality was relatively low in those studies, two studies showed data on oneyear mortality that reached up to $30 \%$, thus, implying that IE by NHGNB is a lethal disease. $^{37,39}$

The present systematic review has some limitations. First of all, it consists of case reports and case series, rendering the quality of evidence contributed low to very low. Furthermore, the possibility of publication bias also exists. 
However, since there is no study in the literature giving specifically data on IE by Proteus species with an adequate number of patients, we could not have used another methodology than the one we used.

\section{Conclusions}

To conclude, this study describes the epidemiology, clinical characteristics, microbiology, treatment and outcomes of IE by Proteus species. P. mirabilis was the most common cause, while mortality was high. Antimicrobial resistance does not seem to be a problem until now, with most of the cases being treated with aminoglycosides, cephalosporins and aminopenicillins.

Authors' contributions statement: PI conceived the study; PI and GV collected and analyzed the data and led the writing. All authors read and approved the final version of the manuscript.

Conflicts of interest: All authors - none to declare.

Funding: None to declare.

References

1. Donnenberg M. Enterobacteriaceae. In: Bennett JE, et al. Mandell, Douglas, and Bennett's Principles and Practice of Infectious Diseases. 8th ed. Philadelphia, PA, USA: Elsevier/Saunders; 2015. Pp. 2516

2. Armbruster CE, Mobley HL. Merging mythology and morphology: the multifaceted lifestyle of Proteus mirabilis. Nat Rev Microbiol. 2012;10:743-54. https://doi.org/10.1038/nrmicro2890

3. Schaffer JN, Pearson MM. Proteus mirabilis and urinary tract infections. Microbiol Spectr. 2015;3:10.1128/microbiolspec.UTI-0017-2013. https://doi.org/10.1128/microbiolspec.UTI-0017-2013

4. Armbruster CE, Mobley HLT, Pearson MM. Pathogenesis of Proteus mirabilis Infection. EcoSal Plus. 2018;8:10.1128/ecosalplus.ESP-0009-2017. https://doi.org/10.1128/ecosalplus.ESP-0009-2017

5. Kwiecińska-Piróg J, Skowron K, Gospodarek-Komkowska E. Primary and secondary bacteremia caused by Proteus spp.: epidemiology, strains susceptibility and biofilm formation. Pol J Microbiol. 2018;67:471-8. https://doi.org/10.21307/pjm-2018-055

6. Wang A, Gaca JG, Chu VH. Management considerations in infective endocarditis: a review. JAMA. 2018;320:72-83. https://doi.org/10.1001/jama.2018.7596

7. Baddour LM, Wilson WR, Bayer AS, et al. Infective endocarditis in adults: diagnosis, antimicrobial therapy, and management of complications: a scientific statement for healthcare professionals from the American Heart Association. Circulation. 2015;132:1435-86. https://doi.org/10.1161/CIR.0000000000000296

8. Kalra A, Cooley C, Tsigrelis C. Treatment of endocarditis due to Proteus species: a literature review. Int J Infect Dis. 2011;15:e222-5.

https://doi.org/10.1016/j.ijid.2010.12.002

9. Stroup DF, Berlin JA, Morton SC, et al. Meta-analysis of observational studies in epidemiology: a proposal for reporting. Meta-analysis of observational studies in epidemiology (MOOSE) group. JAMA. 2000;283:2008-12. https://doi.org/10.1001/jama.283.15.2008

10. Wallace BC, Small K, Brodley CE, Lau J, Trikalinos TA. Deploying an interactive machine learning system in an evidence-based practice center: abstrackr. Proceedings of the 2nd ACM SIGHIT International Health Informatics Symposium. 2012:819-24. https://doi.org/10.1145/2110363.2110464

11. Li JS, Sexton DJ, Mick N, et al. Proposed modifications to the Duke criteria for the diagnosis of infective endocarditis. Clin Infect Dis. 2000;30:633-8.

https://doi.org/10.1086/313753

12. Guyatt GH, Oxman AD, Vist GE, et al. GRADE: an emerging consensus on rating quality of evidence and strength of recommendations. BMJ. 2008;336:924-6. https://doi.org/10.1136/bmj.39489.470347.AD

13. Taniguchi T, Murphy FD. Mural bacterial endocarditis produced by Proteus. J Am Med Assoc. 1950;143:427-8. https://doi.org/10.1001/jama.1950.82910400001006

14. Hiller EJ. Bristle in the heart. Br Med J. 1968;4:812. https://doi.org/10.1136/bmj.4.5634.812

15. Rosen P, Armstrong D. Infective endocarditis in patients treated for malignant neoplastic diseases: a postmortem study. Am J Clin Pathol. 1973;60:241-50. https://doi.org/10.1093/ajcp/60.2.241

16. Carruthers MM. Endocarditis due to enteric bacilli other than Salmonellae: case reports and literature review. Am J Med Sci. 1977;273:203-11. https://doi.org/10.1097/00000441-197703000-00011

17. Venezio FR, Thompson JE, Sullivan H, Subramanian R, Ritzman P, Gunnar RM. Infection of a ventricular aneurysm and cardiac mural thrombus. Survival after surgical resection. Am J Med. 1984;77:551-4. https://doi.org/10.1016/0002-9343(84)90119-0

18. Ananthasubramaniam K, Karthikeyan V. Aortic ring abscess and aortoatrial fistula complicating fulminant prosthetic valve endocarditis due to Proteus mirabilis. J Ultrasound Med. 2000;19:63-6. https://doi.org/10.7863/jum.2000.19.1.63

19. Sawhney N, Palakodeti V, Raisinghani A, Rickman LS, DeMaria AN, Blanchard DG. Eustachian valve endocarditis: a case series and analysis of the literature. J Am Soc Echocardiogr. 2001;14:1139-42. https://doi.org/10.1067/mje.2001.114012

20. Lloyd M, Satterwhite L, Lerakis S. Successfully treated mitral valve Proteus mirabilis endocarditis. Am J Med Sci. 2005;329:267-9. https://doi.org/10.1097/00000441-200505000-00009 
21. Claassen DO, Batsis JA, Orenstein R. Proteus mirabilis: a rare cause of infectious endocarditis. Scand J Infect Dis. 2007;39:373-5. $\underline{\text { https://doi.org/10.1080/00365540600981652 }}$

22. Liu CH, Chang WJ, Chin C. An unusual cause of infective endocarditis: Proteus mirabilis bacteremia from an infected pressure ulcer. Int J Gerontol. 2015;9:243-5. https://doi.org/10.1016/j.ijge.2014.09.003

23. Goel R, Sekar B, Payne MN. Proteus endocarditis in an intravenous drug user. BMJ Case Rep. 2015;2015:bcr2015212447. https://doi.org/10.1136/bcr-2015-212447

24. Rimoldi SG, De Vecchi E, Pagani C, et al. Use of dithiothreitol to dislodge bacteria from the biofilm on an aortic valve in the operating theatre: a case of infective endocarditis caused by Staphylococcus aureus and Proteus mirabilis. Ann Thorac Surg. 2016;102:e357-9. https://doi.org/10.1016/j.athoracsur.2016.03.023

25. Brotzki CR, Mergenhagen KA, Bulman ZP, Tsuji BT, Berenson CS. Native valve Proteus mirabilis endocarditis: successful treatment of a rare entity formulated by in vitro synergy antibiotic testing. BMJ Case Rep. 2016;2016:bcr2016215956. https://doi.org/10.1136/bcr-2016-215956

26. Salsano A, Sportelli E, Borile S, Santini F. Proteus mirabilis bioprosthetic tricuspid valve endocarditis with massive right ventricular vegetation: a new entity in the prosthetic valve endocarditis aetiology. Eur J Cardiothorac Surg. 2016;50:581-2. https://doi.org/10.1093/ejcts/ezw126

27. Albuquerque I, Silva AR, Carreira MS, Friões F. Proteus mirabilis endocarditis. BMJ Case Rep. 2019;12:e230575. https://doi.org/10.1136/bcr-2019-230575

28. Morpeth S, Murdoch D, Cabell CH, et al. Non-HACEK gram-negative bacillus endocarditis. Ann Intern Med. 2007; 147:829-35. https://doi.org/10.7326/0003-4819-147-12-20071218000002

29. Falcone M, Tiseo G, Durante-Mangoni E, et al. Risk factors and outcomes of endocarditis due to nonHACEK gram-negative bacilli: data from the prospective multicenter italian endocarditis study cohort. Antimicrob Agents Chemother. 2018;62:e02208-17. https://doi.org/10.1128/AAC.02208-17

30. Polewczyk A, Janion M, Podlaski R, Kutarski A. Clinical manifestations of lead-dependent infective endocarditis: analysis of 414 cases. Eur J Clin Microbiol Infect Dis. 2014;33:1601-8. https://doi.org/10.1007/s10096-014-2117-8

31. Madhavan T, Quinn EL, Freimer E, et al. Clinical studies of cefazolin and comparison with other cephalosporins. Antimicrob Agents Chemother. 1973;4:525-31. https://doi.org/10.1128/AAC.4.5.525

32. Tolan RW Jr, Kleiman MB, Frank M, King H, Brown JW. Operative intervention in active endocarditis in children: report of a series of cases and review. Clin Infect Dis. 1992;14:852-62. https://doi.org/10.1093/clinids/14.4.852

33. Gonzalez-Juanatey JR, Garcia-Acuna JM, GarciaBengoechea J, et al. Endocarditis with pericardial bioprostheses: clinico-pathologic characteristics, immediate and long term prognosis. J Heart Valve Dis. 1994;3:172-8.

34. Abela GS, Majmudar B, Felner JM. Myocardial abscesses unassociated with infective endocarditis. South Med J. 1981;74:432-4.

https://doi.org/10.1097/00007611-198104000-00016

35. Weinstein L. Infective endocarditis: past, present and future. J R Coll Physicians Lond. 1972;6:161-74.

36. Cahill TJ, Prendergast BD. Infective endocarditis. Lancet. 2016;387:882-93. https://doi.org/10.1016/S0140-6736(15)00067-7

37. Loubet P, Lescure FX, Lepage L, et al. Endocarditis due to gram-negative bacilli at a French teaching hospital over a 6-year period: clinical characteristics and outcome. Infect Dis (Lond). 2015;47:889-95. https://doi.org/10.3109/23744235.2015.1075660

38. Ertugrul Mercan M, Arslan F, Ozyavuz Alp S, et al. NonHACEK Gram-negative bacillus endocarditis. Med Mal Infect. 2019;49:616-20. https://doi.org/10.1016/j.medmal.2019.03.013

39. Veve MP, McCurry ED, Cooksey GE, Shorman MA. Epidemiology and outcomes of non-HACEK infective endocarditis in the southeast United States. PLoS One. 2020; 15:e0230199.

https://doi.org/10.1371/journal.pone.0230199

40. Lin MF, Liou ML, Kuo CH, Lin YY, Chen JY, Kuo HY. Antimicrobial susceptibility and molecular epidemiology of Proteus mirabilis isolates from three hospitals in northern Taiwan. Microb Drug Resist. 2019;25:1338-46. https://doi.org/10.1089/mdr.2019.0066

Please cite this article as:

Ioannou P, Vougiouklakis G. Infective endocarditis by Proteus species: a systematic review. GERMS. 2020;10(3):229-239. doi: 10.18683/germs.2020.1209 


\section{Appendix}

Table 1. Characteristics of the included studies

\begin{tabular}{|c|c|c|c|c|c|c|c|}
\hline Study, year published & $\begin{array}{l}\text { Age } \\
\text { (years) }\end{array}$ & Gender & Site of infection & $\begin{array}{l}\text { Microbiology } \\
\text { of infection }\end{array}$ & $\begin{array}{l}\text { Site of } \\
\text { microorganism } \\
\text { isolation }\end{array}$ & Treatment administered, duration & Infection outcomes, $\mathbf{n}$ \\
\hline Taniguchi et al., $1950^{13}$ & 55 & Female & Mural & Proteus spp. & $\begin{array}{l}\text { Blood } \\
\text { Vegetation } \\
\text { Splenic abscesses }\end{array}$ & $\begin{array}{l}\text { Penicillin, NR } \\
\text { and aminoglycoside, NR }\end{array}$ & $\begin{array}{l}\text { Clinical cure } 0^{a} \\
\text { Overall mortality } 1 \\
\text { IE-specific mortality } 1\end{array}$ \\
\hline Hiller et al., $1968^{14}$ & 1 & Male & $\operatorname{TrV}$ & $\begin{array}{l}\text { Proteus mirabilis } \\
\text { Escherichia coli }\end{array}$ & Blood & Chloramphenicol, NR & $\begin{array}{l}\text { Clinical cure } 0 \\
\text { Overall mortality } 1 \\
\text { IE-specific mortality } 1\end{array}$ \\
\hline Rosen et al., $1973^{15}$ & 52 & Female & NR & Proteus mirabilis & $\begin{array}{l}\text { Blood } \\
\text { Valve } \\
\text { Urine }\end{array}$ & Chloramphenicol, NR & $\begin{array}{l}\text { Clinical cure } 0 \\
\text { Overall mortality } 1 \\
\text { IE-specific mortality } 1\end{array}$ \\
\hline Carruthers et al., $1977^{16}$ & 45 & Male & MV & Proteus mirabilis & $\begin{array}{l}\text { Blood } \\
\text { Urine }\end{array}$ & $\begin{array}{l}\text { Aminopenicillin, } 12 \text { days } \\
\text { and aminoglycoside, } 12 \text { days } \\
\text { then carbenicillin, } 3 \text { days } \\
\text { and aminoglycoside, } 3 \text { days }\end{array}$ & $\begin{array}{l}\text { Clinical cure } 0 \\
\text { Overall mortality } 1 \\
\text { IE-specific mortality } 0\end{array}$ \\
\hline Venezio et al., $1984^{17}$ & 67 & Male & Mural & Proteus mirabilis & Blood & $\begin{array}{l}\text { Cephalosporin, } 42 \text { days post-surgery } \\
\text { and aminoglycoside, } 42 \text { days post- } \\
\text { surgery } \\
\text { Surgery }\end{array}$ & $\begin{array}{l}\text { Clinical cure } 1 \\
\text { Overall mortality } 0\end{array}$ \\
\hline $\begin{array}{l}\text { Ananthasubramaniam et } \\
\text { al., } 2000^{18}\end{array}$ & 50 & Female & AoV & Proteus mirabilis & $\begin{array}{l}\text { Blood } \\
\text { Urine }\end{array}$ & $\begin{array}{l}\text { NR } \\
\text { Surgery }\end{array}$ & $\begin{array}{l}\text { Clinical cure } 0 \\
\text { Overall mortality } 1 \\
\text { IE-specific mortality } 1 \\
\text { Clinical cure } 0\end{array}$ \\
\hline Sawhney et al., $2001^{19}$ & 68 & Male & Eustachian valve & Proteus vulgaris & Blood & NR & $\begin{array}{l}\text { Overall mortality } 1 \\
\text { IE-specific mortality } 1\end{array}$ \\
\hline Lloyd et al., $2005^{20}$ & 64 & Male & MV & Proteus mirabilis & Blood & $\begin{array}{l}\text { Cephalosporin, NR } \\
\text { Surgery }\end{array}$ & $\begin{array}{l}\text { Clinical cure } 1 \\
\text { Overall mortality } 0\end{array}$ \\
\hline Claassen et al., $2007^{21}$ & 58 & Female & MV & Proteus mirabilis & $\begin{array}{l}\text { Blood } \\
\text { Urine }\end{array}$ & Cephalosporin, 28 days & $\begin{array}{l}\text { Clinical cure } 1 \\
\text { Overall mortality } 0\end{array}$ \\
\hline Kalra et al., $2011^{8}$ & 62 & Female & MV & Proteus mirabilis & $\begin{array}{l}\text { Blood } \\
\text { Urine }\end{array}$ & $\begin{array}{l}\text { Aminopenicillin, } 42 \text { days } \\
\text { and aminoglycoside, } 42 \text { days }\end{array}$ & $\begin{array}{l}\text { Clinical cure } 1 \\
\text { Overall mortality } 0\end{array}$ \\
\hline
\end{tabular}




\begin{tabular}{|c|c|c|c|c|c|c|c|}
\hline Study, year published & $\begin{array}{l}\text { Age } \\
\text { (years) }\end{array}$ & Gender & Site of infection & $\begin{array}{l}\text { Microbiology } \\
\text { of infection }\end{array}$ & $\begin{array}{l}\text { Site of } \\
\text { microorganism } \\
\text { isolation }\end{array}$ & Treatment administered, duration & Infection outcomes, $\mathrm{n}$ \\
\hline Liu et al., $2015^{22}$ & 71 & Male & AoV & Proteus mirabilis & $\begin{array}{l}\text { Blood } \\
\text { Wound }\end{array}$ & $\begin{array}{l}\text { Aminopenicillin, NR } \\
\text { and aminoglycoside, NR } \\
\text { then cephalosporin, NR } \\
\text { and fosfomycin, NR } \\
\text { and aminoglycoside, NR }\end{array}$ & $\begin{array}{l}\text { Clinical cure } 1 \\
\text { Overall mortality } 1 \\
\text { IE-specific mortality } 0\end{array}$ \\
\hline Goel et al., $2015^{23}$ & 42 & Male & $\operatorname{TrV}$ & Proteus mirabilis & Blood & Aminopenicillin, 42 days & $\begin{array}{l}\text { Clinical cure } 1 \\
\text { Overall mortality } 0\end{array}$ \\
\hline Rimoldi et al., $2016^{24}$ & 39 & Female & AoV & $\begin{array}{l}\text { Proteus mirabilis } \\
\text { Staphylococcus } \\
\text { aureus (MSSA) }\end{array}$ & $\begin{array}{l}\text { Blood } \\
\text { Valve }\end{array}$ & $\begin{array}{l}\text { Carbapenem, } 42 \text { days } \\
\text { and daptomycin, } 42 \text { days }\end{array}$ & $\begin{array}{l}\text { Clinical cure } 1 \\
\text { Overall mortality } 0\end{array}$ \\
\hline Brotzki et al., $2016^{25}$ & 59 & Male & AoV & Proteus mirabilis & $\begin{array}{l}\text { Blood } \\
\text { Urine }\end{array}$ & $\begin{array}{l}\text { Carpbapenem, NR } \\
\text { then cephalosporin, } 42 \text { days } \\
\text { and aminoglycoside, } 42 \text { days }{ }^{b}\end{array}$ & $\begin{array}{l}\text { Clinical cure } 1 \\
\text { Overall mortality } 0\end{array}$ \\
\hline Salsano et al., $2016^{26}$ & 43 & Female & $\operatorname{TrV}$ & Proteus mirabilis & $\begin{array}{l}\text { Blood } \\
\text { Urine } \\
\text { BAL }\end{array}$ & $\begin{array}{l}\text { NR } \\
\text { Surgery }\end{array}$ & $\begin{array}{l}\text { Clinical cure } 1 \\
\text { Overall mortality } 0\end{array}$ \\
\hline Albuquerque et al., $2019^{27}$ & 62 & Male & AoV & Proteus mirabilis & $\begin{array}{l}\text { Prosthetic valve } \\
\text { BAL }\end{array}$ & $\begin{array}{l}\text { Cephalosporin, } 42 \text { days } \\
\text { and quinolone, } 42 \text { days } \\
\text { Surgery }\end{array}$ & $\begin{array}{l}\text { Clinical cure } 1 \\
\text { Overall mortality } 0\end{array}$ \\
\hline
\end{tabular}

a Defined as clinical resolution of the infection as a result of treatment.

${ }^{b}$ Monotherapy with carbapenem led to clinical failure. Time-kill assays revealed that the combination of ceftriaxone and gentamicin were associated with the most efficient bacterial killing.

Each study included one patient.

AoV - aortic valve; BAL - bronchoalveolar lavage; MV - mitral valve; NR - not reported; $\operatorname{TrV}$ - tricuspid valve. 
Table 2. Characteristics of 16 patients with infective endocarditis by Proteus species. Values show cases among patients with available data.

\begin{tabular}{|c|c|}
\hline Characteristic & Value \\
\hline Male, n (\%) & 9 out of $16(56.3 \%)$ \\
\hline Age, mean $( \pm S D)$ in years & $52.4( \pm 16.9)$ \\
\hline \multicolumn{2}{|l|}{ Predisposing factors } \\
\hline Prosthetic valve, n (\%) & 4 out of $16(25 \%)$ \\
\hline IVDU, n (\%) & 3 out of $16(18.8 \%)$ \\
\hline Previous IE, n (\%) & 2 out of $16(12.5 \%)$ \\
\hline CVC, n (\%) & 1 out of $16(6.3 \%)$ \\
\hline Foreign material in heart (traumatic), $\mathrm{n}(\%)$ & 1 out of $16(6.3 \%)$ \\
\hline \multicolumn{2}{|l|}{ Site of infection inside heart } \\
\hline Aortic valve, n (\%) & 5 out of $15(33.3 \%)$ \\
\hline Mitral valve, n (\%) & 4 out of $15(26.7 \%)$ \\
\hline Tricuspid valve, $\mathrm{n}(\%)$ & 3 out of $15(20 \%)$ \\
\hline Mural endocardium, n (\%) & 2 out of $15(13.3 \%)$ \\
\hline Eustachian valve, $\mathrm{n}(\%)$ & 1 out of $15(6.7 \%)$ \\
\hline \multicolumn{2}{|l|}{ Microbiology } \\
\hline Proteus mirabilis, n (\%) & 14 out of $16(87.5 \%)$ \\
\hline Proteus vulgaris, $\mathrm{n}(\%)$ & 1 out of $16(6.3 \%)$ \\
\hline Proteus spp., n (\%) & 1 out of $16(6.3 \%)$ \\
\hline Polymicrobial, n (\%) & 2 out of $16(12.5 \%)$ \\
\hline Staphylococcus aureus, n (\%) & 1 out of $16(6.3 \%)$ \\
\hline Escherichia coli, n (\%) & 1 out of $15(6.7 \%)$ \\
\hline \multicolumn{2}{|l|}{ Antimicrobial resistance } \\
\hline Trimethoprim-sulfamethoxazole, n (\%) & 1 out of $3(33.3 \%)$ \\
\hline Quinolones, n (\%) & 1 out of $4(25 \%)$ \\
\hline Aminopenicillins, $\mathrm{n}(\%)$ & 1 out of $6(16.7 \%)$ \\
\hline Cephalosporins, n (\%) & 0 out of $8(0 \%)$ \\
\hline Piperacillin/tazobactam, n (\%) & 0 out of $3(0 \%)$ \\
\hline Carbapenems, n (\%) & 0 out of $4(0 \%)$ \\
\hline Aminoglycosides, $\mathrm{n}(\%)$ & 0 out of $9(0 \%)$ \\
\hline \multicolumn{2}{|l|}{ Method of diagnosis } \\
\hline Transesophageal echocardiography, n (\%) & 6 out of $16(37.5 \%)$ \\
\hline Transthoracic echocardiography, n (\%) & 4 out of $16(25 \%)$ \\
\hline Echocardiography non-diagnostic ${ }^{*}, \mathrm{n}(\%)$ & 1 out of $16(6.3 \%)$ \\
\hline Autopsy, n (\%) & 4 out of $16(25 \%)$ \\
\hline \multicolumn{2}{|l|}{ Clinical characteristics } \\
\hline Feverish, n (\%) & 15 out of $15(100 \%)$ \\
\hline Septic, n (\%) & 11 out of $13(84.6 \%)$ \\
\hline Concurrent UTI, n (\%) & 7 out of $15(43.8 \%)$ \\
\hline Embolic phenomena, n (\%) & 6 out of $14(42.9 \%)$ \\
\hline Heart failure, n (\%) & 2 out of $14(14.3 \%)$ \\
\hline Immunologic phenomena, n (\%) & 2 out of $14(14.3 \%)$ \\
\hline Paravalvular abscess, n (\%) & 2 out of $15(13.3 \%)$ \\
\hline Concurrent SSTI, n (\%) & 1 out of $16(6.3 \%)$ \\
\hline \multicolumn{2}{|l|}{ Treatment } \\
\hline Duration of treatment in weeks, median (IQR) & $6(6,6)$ \\
\hline Aminoglycosides, n (\%) & 6 out of $13(46.2 \%)$ \\
\hline Cephalosporin, n (\%) & 6 out of $13(46.2 \%)$ \\
\hline Aminopenicillin, n (\%) & 3 out of $13(23.1 \%)$ \\
\hline Chloramphenicol, n (\%) & 2 out of $13(15.4 \%)$ \\
\hline Carbapenem, n (\%) & 1 out of $13(7.7 \%)$ \\
\hline Quinolone, n (\%) & 1 out of $13(7.7 \%)$ \\
\hline Fosfomycin, n (\%) & 1 out of $13(7.7 \%)$ \\
\hline Carbenicillin, n (\%) & 1 out of $13(7.7 \%)$ \\
\hline
\end{tabular}


Proteus endocarditis systematic review - Ioannou et al. • Review

\begin{tabular}{ll}
\hline Characteristic & Value \\
\hline Penicillin, n (\%) & 1 out of $13(7.7 \%)$ \\
Daptomycin, n (\%) & 1 out of $13(7.7 \%)$ \\
$\quad$ Surgical intervention, n (\%) & 5 out of $16(31.3 \%)$ \\
Outcomes & \\
$\quad$ Clinical cure, n (\%) & 10 out of $16(62.5 \%)$ \\
Deaths due to infection, n (\%) & 5 out of $16(31.3 \%)$ \\
Deaths overall, n (\%) & 7 out of $16(43.8 \%)$ \\
\hline
\end{tabular}

*Diagnosis of IE met current (Duke's) diagnostic criteria.

CVC - central venous catheter; IE - infective endocarditis; IVDU - intravenous drug use; IQR interquartile range; SD - standard deviation; SSTI - skin and soft tissue infection; UTI - urinary tract infection. 